て，その境界面に比較的近い 1 点に一つの集中モーメ ントが作用した場合と，偶力（ダブレット）が作用し た場合の解を求め，後者の水平方向ダブレットの場合 と垂直方向ダブレットの場合の 2 個の解を重ね合わせ たものが，前者の解と一致することを確かめた。また $K_{1}={ }_{2} K=2$ [平面応力のとき $K=(3-\nu) /(1-\nu)$, 平面 ひずみのとき $K=3-4 \nu$, 添字 1,2 は 2 個の板のそ れそれの值であることを意味し，ンはポアンン比了の 場合の種々の $T=G_{2} / G_{1}[G$ はせん断弾性係数 $]$ の值 についての数值計算を行なったままた完全結合の場合 の光弾性実験結果を示した。

(1) 昭 40-3-18 関西支部第 40 期定時総会講演会䎲わいて請演, 原 稿受付 昭 40-7-20, 本論文は論文集 235 号に揭载の予定. (2) 正 員, 立命館大学理工学部. (3) 准貣, 同志社大学工学部. (4) Northwestern University.

534.013 : 621-232

多数の粘性感衰要素を有するクランク軸系 ねじり非規準振動モードの電子計算機によ る研究 (1)

$$
\text { 神田好作 }{ }^{(2)}
$$

ビスカス・ダンパを有するクランク軸系の強制振動 においては，その強力な減衰作用により各䐝量の振動 位相はそれそれ異なり，また絶対比振幅，相対比振幅 は規準振動そードのそれそれの值より大なる非規準振 動をなす。その結果としてダンパ・タースの単位振幅 当たりの各部の応力が増大して，ダンパの減衰による 実振幅の減少の割には実応力は減少しない，また共振 点の近傍の振動モートの変化の状態によっては, 実庆 力の最大になる回転数は実振幅の最大となる共振点之 は異なる位置に存在するそここでこれらの事実を調べ るために，ダンパ，機関，プロペラ等の多くの粘性減 衰を有するクランク軸系の強制振動計算用プログラム を作成した。そして電子計算機 IBM-7044を用いて， 高速, 高出力ディーゼル機関の 3 節振動にビスカス . ダンパをきかせた場合について，共振点近傍ならびに 3 節共振点から 2 節共振点への実振幅, 振動モード, および央応力の变化について解明した結果について論 ずる。

(1) 昭 39-11-13 関西支部創立 40 周年記念講演会において論文講演 として講演, 原稿受付 昭 39-9-17, 本論文は論文集 235 号に揭載 の予定. (2) 正員, 三菱重工業会社.

\section{$539.382: 621-462$}

軸力を受けるらせん状波付管の応力 ${ }^{(1)}$

$$
\text { 吉田章(2) }
$$

らせん状波付管が軸方向に弓張変形を生ずるときの 応力解析を行なった。このような管に対しては回転非 対称かくの曲げ理論を用いる必要があるが, 解析を容 意にするためには座標のとり方が重要な間題である.

ここでは円筒座標 $(\boldsymbol{r}, \theta, z)$ の中で, $\mathrm{X}, \mathrm{Y}$ 面から の高さ $z$ のかわりに基準らせんからの高さ $\phi$ 用い たらせん座標 $(r, \theta, \phi)$ をって基本座標系とした。 この座標系によると曲面の形が $\phi$ みの関数として表 わされる便宜がある反面, 斜交系であるため庥力解析 が複雑になる久点がある。そこでこの座標系をもとに して直艾系の標構を作りこれに関して汒力やひずみ の解析を行なうという二重系を採用した。

正弦波形を波づけした管にっこうして得られた結果
を適用し，電子計算機による数値積分を行なった。ま た計算された結果について，回転対称かくの応力との 比較を行なった。

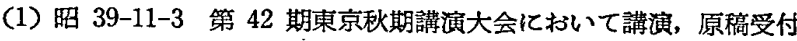
昭 39-12-15, 本稐文は論文集 235 号に揭載の予定. (2) 正員, 古 河電気工業会社

621.833.3.01 : 539.384

\section{はすば歯車の歯元応力 ${ }^{(1)}$}

\section{釘 宮}

肇(2)

すぐば円筒歯車の菡元応力については，古くから多 くの研究者によってその計算式が導かれているが，は すば歯車の歯元応力については，今のところ厳密な計 算式はなく，すぐぱ円筒歯車の計算式を近似的に修正 したものがあるにすぎない。

本研究は，はすば歯車の歯を有限幅の片持平板，歯 の接触線にそった分布荷重を単位長さ当たりの集中荷 重の集まりとみなし，片持平板に垂直な集中荷重が作 用するときの曲げモーメントの計算結果を用いて，は すば歯車の歯元庥力を求める計算方法を導き，この方 法で求めた歯元応力を実験結果と比較考察したもの で、つぎの結論を得た。

1.はすば歯車の呼称歯元応力は，本報告で導いた 計算方法によって計算することができる.

2.はすば歯車の最大歯元応力は，いわゆる外の単 一かみあい点に近い位置で生ずる.

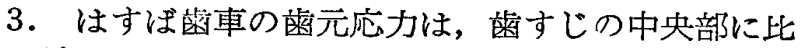
較して両端部で若干小さい.

(1) 昭 40-8-30 第 43 期東京秋期講演大会において論文講演として 講演, 原稿受付 昭 40-5-6, 本論文は論文集 235 号に揭載の予定. （2）正員，住友金属工業会社.

\subsubsection{3}

\section{遊星蒾車式変動トルク発生装置 ${ }^{(1)}$}

$$
\text { 矢田恒二(2) }
$$

本報は太陽歯車の回りを回る遊星歯車に, 不平衡質 量を取付けて変動トルクを発生させる装置について述 べている.すなわち遊狌歯車に回転運動を与えると， この不平衡質量には太陽歯車軸に関する遠心力と，遊 星歯車軸に関する遠心力およびコリオリの力が発生す る.これらの力は太陽歯車軸と, 遊星歯車のキャリア 軸に対して，别個に変動トルクを与える. 著者はこの 装置の変動トルク発生機構の解析を行ない笑験によ って確かめた結果, 太陽歯車を出力要素とするほう が, キャリアを出力要素とするより, 発生トルクの調 整が容易であることからすぐれていることがわかっ た。またこの装置の三，三の応用例についても述へて いる.

(1) 昭 40-10-16 第 43 期全国大会講演会において論文講演として講 演, 原稿受付 昭 40-6-1, 本論文は論文集 235 号に揭載の予定.

(2) 正員, 機械試験所.

$539.43 .013: 620.179 .1$

X 線による切欠き材の疲れ破壊 に関する研究 ${ }^{(1)}$

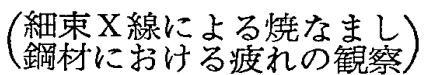

$$
\text { 平 修二 }{ }^{(2)} \text {, 林 建吉 }{ }^{(3)}
$$

細束 X線技術を焼なました低炭素鋼における波れ機 